\title{
Towards more equitable money creation
}

Money creation should be governed with an eye on ethics, but its current path follows an unfair formula that entrenches injustice. Philosopher and Dietsch of the University of Victoria, British Columbia, Canada, points out a number of biases in the current monetary system. He suggests a normative framework for assessing what a more equitable money creation system should look like, and proposes one alternative model.
It's controversial, but it's a start.

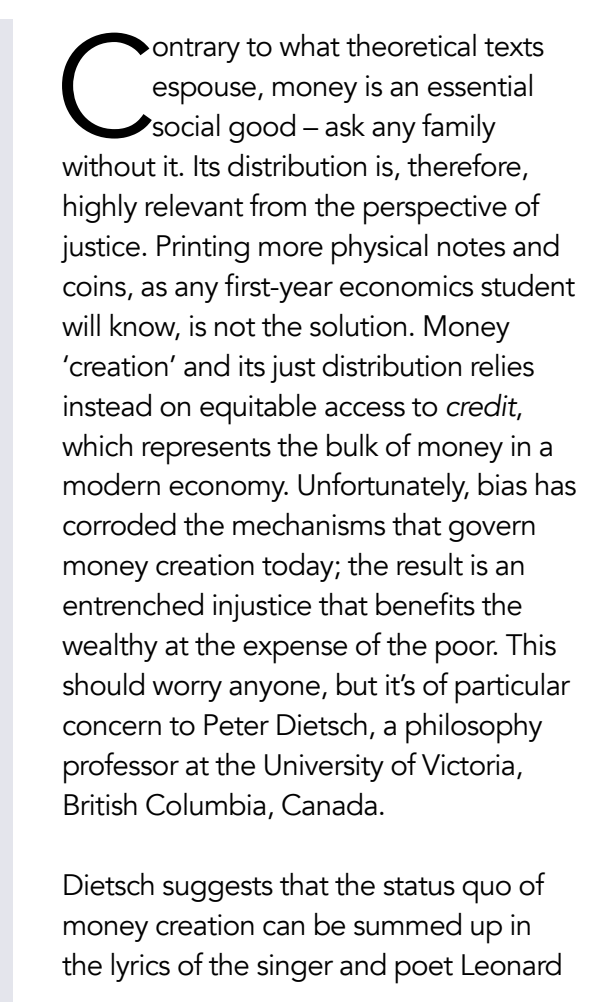

Cohen: 'Everybody knows the fight was fixed, the poor stay poor, the rich get the system and consider alternatives.

He starts from the observation that money confers freedom. However the system by which money is created produces unintended and undesired consequences - the way credit is allocated leads to some people enjoying less freedom than others through no fault of their own. It is a syste that is neither ethical nor meritocratic but prejudiced against those without collateral. It is also unstable.

\section{MAKING THE WORLD GO ROUND} The money powering the global economy is essentially an IOU system. In its most basic form - cash - it is a promise from sum displayk to pay the bearer the sum displayed on the note. The most deposits issued as loans to individuals and nonfinancial entities, and loans between commercial banks, known as inter-bank lending. A third form of IOU are central bank resenves - just as individuals have deposits with commercial banks, those banks have deposits with central banks. This entire system relies on certified trust.

A simple example: a bank will issue an individual a mortgage or a loan to invest in, say, a business, if the applicant shows they can service the loan or have collateral the bank could secure should things go south. The creditor's capacity to contribute to a broader societal good is not a viable measurement of doesn't come into it.

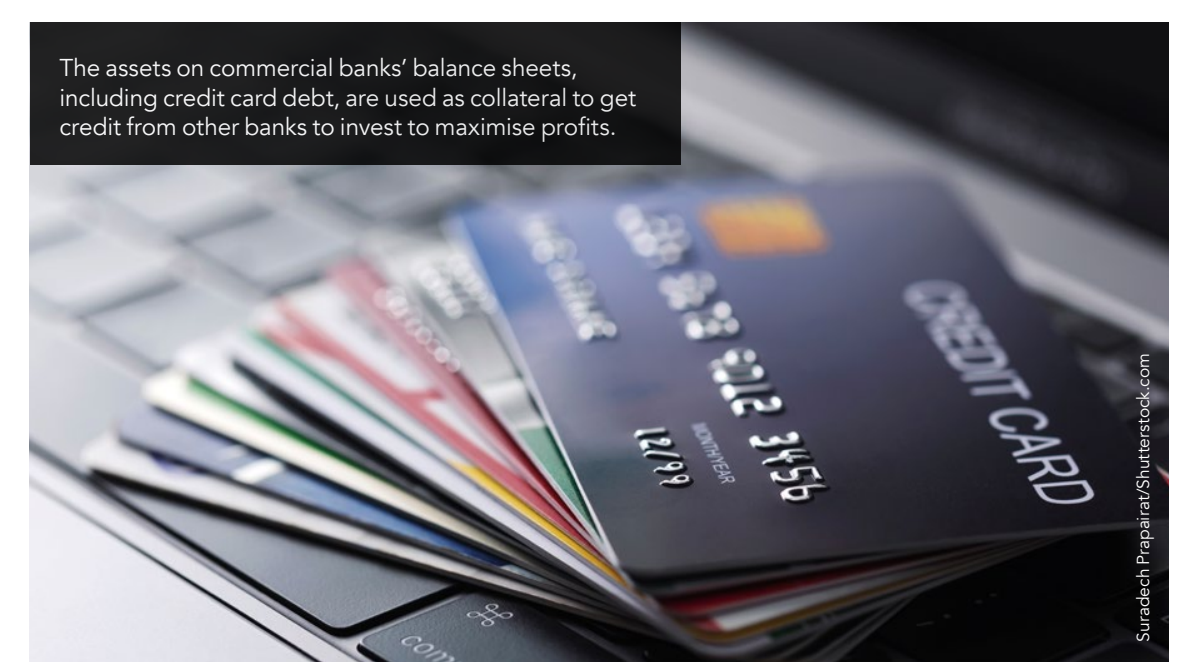

Inter-bank lending follows the same rules: credit markets provide commercial banks with leverage to pursue profit. The assets sitting on their balance sheets goventunt get credit from other banks to invest to maximise profits for shareholders a bonuses to executive teams. These are the primany beneficiaries of interbank lending. The claim that the financial benefits eventually 'trickle down' to the more needy is overshadowed by the looming reality that the newly created money often ends up in asset markets such as stocks or real estate, as opposed to incentivising commercial banks to issue more loans to those who need them. Result: further bias within the benefits the wealthy.

So, where do central banks fit into this unjust money creation system? Their footprints are in the chaos after the 2008 financial collapse. When commercia banks, especially in the US, saw their assets - invariably lent by other financial institutions - suddenly become worthless, central banks injected new money onto their balance sheets in the form of cent bank reserves. By essentially buying useless assets from commercial banks and other private institutions, thus creating money - a process called quantitative easing - the prime beneficiaries were again financial institutions. They were given a hand up - or more correctly, a handout - and returned to business. One reason they had access to such credit was because they were too big central banks in launching quantitative easing, such benefits rarely trickled down: the bias remained.

TOWARDS A NORMATIVE AMEWORK

Dietsch points to one positive from the monetany policy response reignited interest in the normative dimensions of money and its creation.

Bias has corroded the mechanisms that govern money creation today.

Fixing this demands a clearer idea of what justice in a monetary system looks like. If, as Dietsch claims, bias is ingrained in the system, we need a normative benchmark against which we can evaluate biases. That will guide us towards a credt disthe wh framework

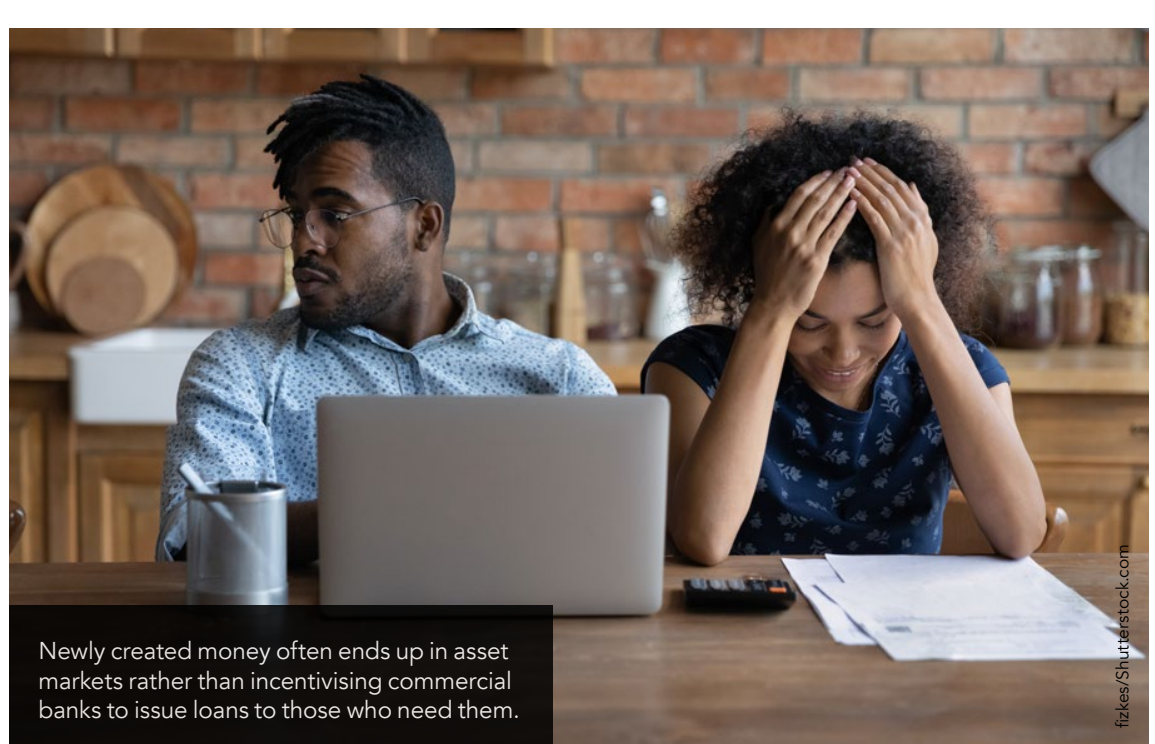
White is is tiated freedom is not unjust resulting inequality is undeserved.

Dietsch admits credit has its flipside on issues of freedom: debt. Those accorded credit are indebted to the creditor, as nyone who starts a career in the shadow o student loan knows. Similarly, having to enter into debt to acquire ther fundamental rights such as healthcare hardly enhances
an individual's freedom. an individual's freedom. goods such as education

health care, but extra cash to satisfy secondary needs, having access to extra money through credit arguably outweighs any constrining aspects of

A key point here is to distinguish voice of economists and philosophers is patchy on questions of justice ey creation.

As one of the rare exceptions, the late good starting point He believed money and freedom were intertwined - given that money is a necessary condition to acquire most goods and services, lacking means one is 'liable to interference'. At its most basic, if someone simply takes something they cannot afford, this will invite strict retribution. Hence, for Cohen, 'money confers freedom'. No reeds entirely free from interference, and While diff not absolute - it is relative. the structis the to access to money and 
more than they receive in deposits. Meanwhile central banks would make mechanism of the credit mantibsion directly injecting or withdrawing money from consumers - for instance through instrument that Milton Friedman coined 'helicopter money'.

The concept of 'full reserve banking' has a long pedigree, having been proposed by Ining Fisher in the 1930s and regularly privileges accorded to commercial

\section{CALL FOR CHANG}

To achieve a fairer system, it's clear some fundamental things need to change. Dietsch discusses one reform proposal, not so much because he necessarily believes it represents the best way forward, but to demonstrate that a less biased system of money creation is possible.

Today, central banks pursue the objective of price stability - the stable level of prices of money over time - by using the credt market as a transmission mechanism P simply, they open or close the valve of money creation, but commercial banks play an important role in deciding where

Money confers freedom - but the way credit is
allocated results in some people enjioying allocated results in som
freedom than others.

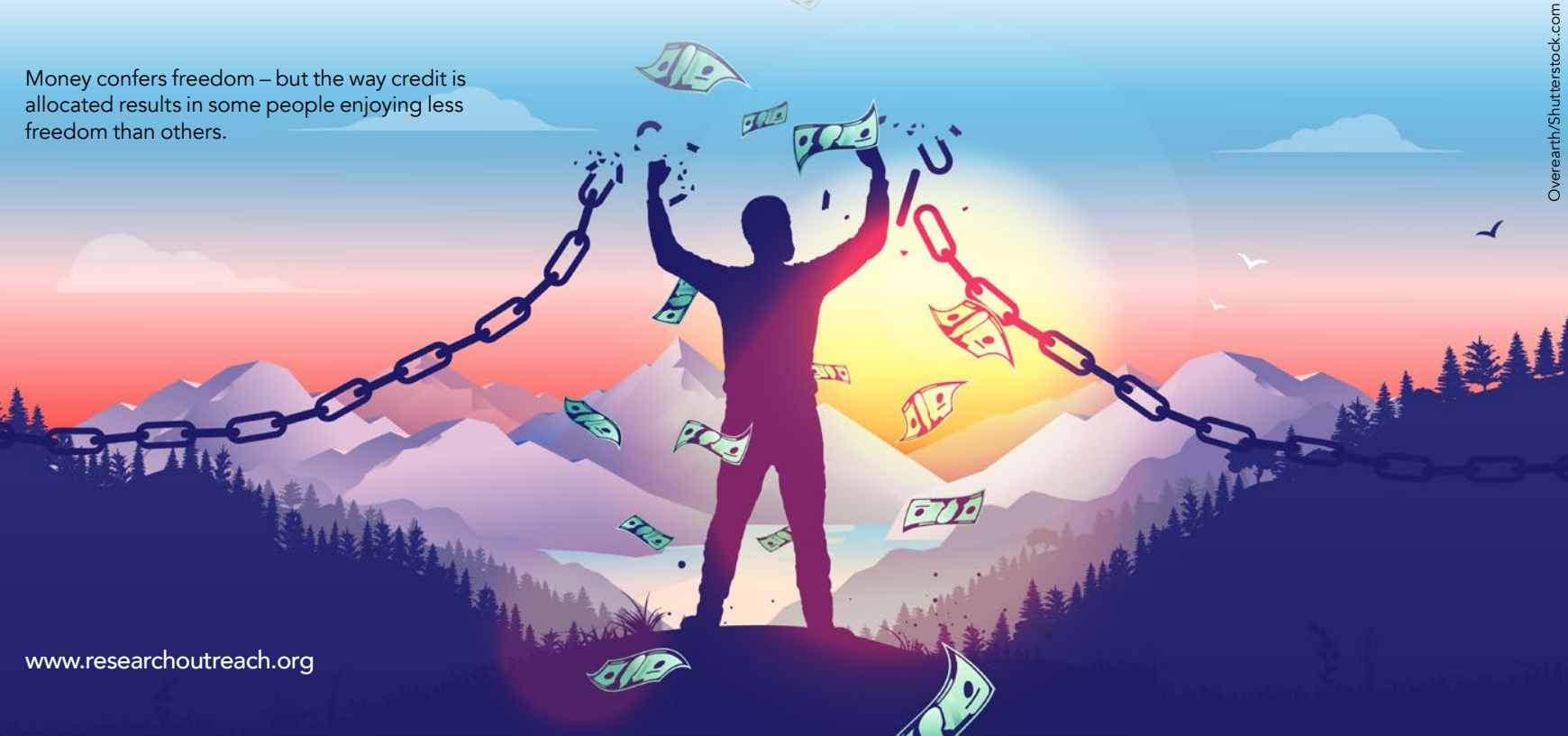

\section{Professor Peter Dietsch}

E: pdietsch@uvic.ca T: $+12507217411 \quad$ W: peterdietsch.openum.ca defended by a minority of economists since. It is controversial and is yet to find favour with any country's priman credit institutions, but that certainly doesn't mean we should dismiss it out of hand. For eliminating bias in the issuing of credit, it has considerable privieges acco reduce the enormous asset holdes, thereby throfling the fol that feeds saset price bubbles Thanks to increased stability, bailouts would

theoretically, be unnecessary. the notion that commercial banks a is a little simplistic. A country's financial

The voice of economists and philosophers is patchy on questions of justice around money creation.

Research Objectives

Issues of economic ethics, normative dimensions of monetary policy, tax justice, and income inequalities

\section{Detail}

\section{Address}

Department of Philosophy

PO Box 1700 STN CSC

Victoria, BC V8W 2 Y2

Peter Dietsch is a professor in philosophy at the University of Victoria, Canada. His research focuses on questions of economic ethics. He is the author of Catching Capital The Ethics of Tax Competition (Oxford University Press, Pel and co-author of Do Central Banks Serve the People? (Polity, 2018)

Funding

stabily eles on the fractional reserve $\begin{aligned} & \text { banking system, where only a fraction } \\ & \text { of bank deposits is supported by actual a banking. Increased interest rates } \\ & \text { a likely outcome - might level the playing }\end{aligned}$ $\begin{array}{ll}\begin{array}{l}\text { of bank deposits is supported by actual a likely outcome }- \text { might level the playing } \\ \text { cash on hand. The result is a system }\end{array} & \text { fields between the rich and the poor and }\end{array}$ woven together by credit upon credit squeeze the level of relative freedom suddenly demanding their money. It's not also become more risk-averse, potentially difficult to comprehend why commercial reducing overall growth. banks prefer issuing credit based on minimal risk instead of maximum need.

What is the alternative? It is an economy with 'full reserve banking' in the sense that commercial banks cannot lend

As Dietsch points out, even though fullreserve banking may not be the last word on the issue, it is a vital starting point to discussing distributive justice and a more equitable system of money creation.
Social Sciences and Humanities Research Council of Canada

\begin{tabular}{l|l} 
University & Philosophy \\
of Victoria
\end{tabular}

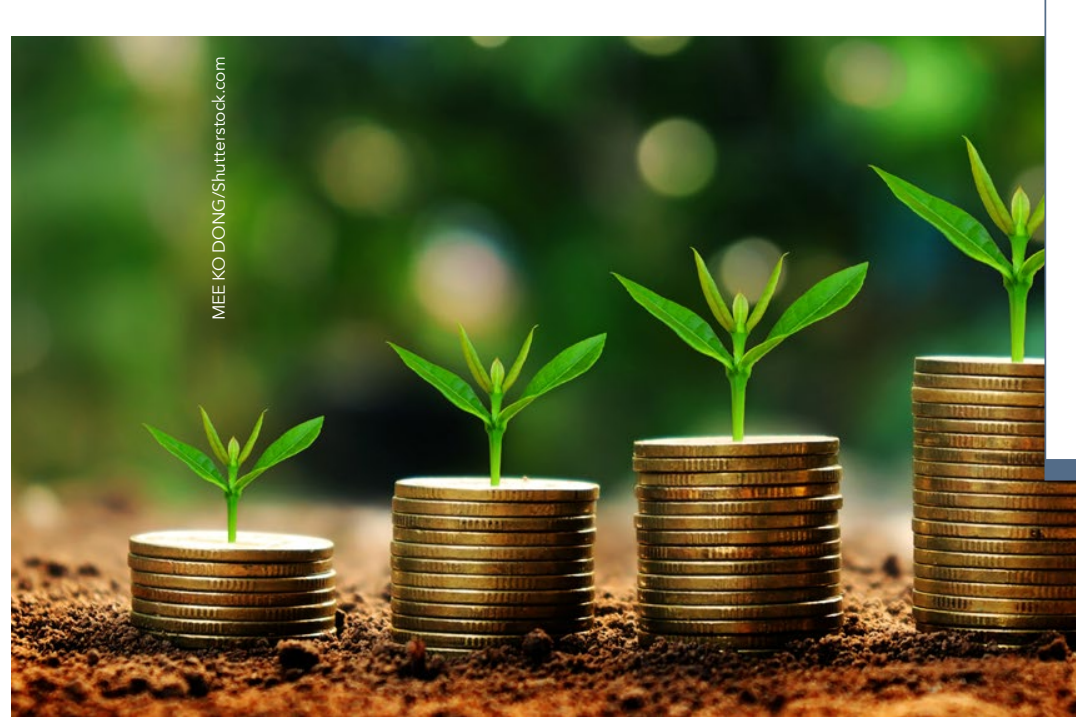

References

Dietsch, P, (2021) Money Creation, Debt and Justice. Politics, Philosophy \& Economics, 20(2), 151-179. doi org/10.1177/1470594X21999736

Dietsch, $P,(2021)$ Designing the fiscal-monetary nexus: policy options for the EU. 1938191

Dietsch, P, (2020) Independent Agencies, Distribution, and Legitimacy: The Case of Central Banks. American S0003055419000790

Dietsch, P, Claveau, F, Fontan, C, (2018) Do Central Banks Serve the People? Polity, Cambridge. politybooks.com/ bookdetail/?isbn $=9781509525768$

Fontan, C, Claveau, F, Dietsch, P, (2016) Central banking and inequalities: Taking off the blinders. Politics, Philosophy \& Economics, 15(4), 319-357.

doi.org/10.1177/1470594X16651056

\section{Personal Response}

\section{In a more equitable money creation system, what} with credit?

II First, we should limit the ways in which merely having

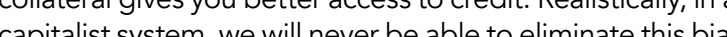

entirely, but we can certainly get rid of some of the more egregious forms it takes - for instance on the inter-bank lending market. This would also make our financial system more stable.

Second, we also create money collectively. Government expenditures, ultimately, are financed through money
creation. Here, equity means more than formal equality, namely structuring government spending in a way that promotes
members. 